\title{
Phosphoinositide 3-kinase couples NMDA receptors to superoxide release in excitotoxic neuronal death
}

\author{
This article has been corrected since Online Publication and a corrigendum has also been published
}

\author{
AM Brennan-Minnella ${ }^{*, 1}$, Y Shen ${ }^{1}$, J El-Benna ${ }^{2}$ and RA Swanson ${ }^{1}$
}

Sustained activation of neuronal $\mathrm{N}$-methly $\mathrm{D}$-aspartate (NMDA)-type glutamate receptors leads to excitotoxic cell death in stroke, trauma, and neurodegenerative disorders. Excitotoxic neuronal death results in part from superoxide produced by neuronal NADPH oxidase (NOX2), but how NMDA receptors are coupled to neuronal NOX2 activation is not well understood. Here, we identify a signaling pathway coupling NMDA receptor activation to NOX2 activation in primary neuron cultures. Calcium influx through the NR2B subunit of NMDA receptors leads to the activation of phosphoinositide 3-kinase (PI3K). Formation of phosphatidylinositol $(3,4,5)$-triphosphate (PI $(3,4,5) \mathrm{P} 3)$ by PI3K activates the atypical protein kinase C, PKC zeta (PKC $\zeta)$, which in turn phosphorylates the $\mathrm{p} 47^{\mathrm{phox}}$ organizing subunit of neuronal NOX2. Calcium influx through NR2B-containing NMDA receptors triggered mitochondrial depolarization, NOX2 activation, superoxide formation, and cell death. However, equivalent magnitude calcium elevations induced by ionomycin did not induce NOX2 activation or neuronal death, despite causing mitochondrial depolarization. The PI3K inhibitor wortmannin prevented NMDA-induced NOX2 activation and cell death, without preventing cell swelling, calcium elevation, or mitochondrial depolarization. The effects of wortmannin were circumvented by exogenous supply of the PI3K product, $\mathrm{PI}(3,4,5) \mathrm{P3}$, and by transfection with protein kinase $\mathrm{M}$, a constitutively active form of $\mathrm{PKC} \zeta$. These findings demonstrate that superoxide formation and excitotoxic neuronal death can be dissociated from mitochondrial depolarization, and identify a novel role for PI3K in this cell death pathway. Perturbations in this pathway may either increase or decrease superoxide production in response to NMDA receptor activation, and may thereby impact neurological disorders, in which excitotoxicity is a contributing factor.

Cell Death and Disease (2013) 4, e580; doi:10.1038/cddis.2013.111; published online 4 April 2013

Subject Category: Neuroscience

Excessive activation of $N$-methly $D$-aspartate (NMDA)-type glutamate receptors leads to excitotoxic cell death in acute neurological disorders, such as stroke and trauma, and also in chronic disorders, such as Alzheimer's disease. ${ }^{1-4}$ Cell death in excitotoxicity requires the calcium-dependent production of both nitric oxide and superoxide. ${ }^{5-9}$ Nitric oxide is produced by neuronal nitric oxide synthase, in response to calcium entry through NMDA receptors. ${ }^{8}$ Superoxide production was long considered a result of mitochondrial calcium uptake; ${ }^{10,11}$ however, recent studies suggest instead that NADPH oxidase is the major source of NMDA-induced superoxide production. ${ }^{5,12-15}$ Neuronal NADPH oxidase has also been identified as a primary source of brain oxidative stress in stroke, aging, and other disorders, ${ }^{16-18}$ but little is known about the regulation of neuronal NADPH oxidase.

NOX2 is the isoform of NADPH oxidase most abundantly expressed by brain neurons. ${ }^{19}$ NOX2 is also the most abundant isoform expressed by phagocytes, where its regulation and function have been extensively studied. NOX2 is composed of two membrane bound subunits, $p 22^{\text {phox }}$ and gp $91^{\text {phox }}$ (the catalytic unit), and three cytosolic subunits, $\mathrm{p} 47^{\text {phox }}, \mathrm{p} 67^{\text {phox }}$, and $\mathrm{p} 40^{\text {phox }}$. Phosphorylation of $\mathrm{p} 47^{\text {phox }}$ induces its translocation to cell membranes, where it interacts with the other subunits, membrane phospholipids, and Rac GTPase to form an active enzyme complex. ${ }^{19,20} \mathrm{p} 47^{\text {phox }}$ is phosphorylated by protein kinase C (PKC), with different PKC subtypes utilized in different cell types. In neurons, inhibition of the calcium-insensitive PKC subtype, PKC zeta $\left(\mathrm{PKC}_{\zeta}\right)$, prevents NMDA-induced superoxide production, ${ }^{5}$ but how NMDA receptor activation triggers $\mathrm{PKC} \zeta$ activation and subsequent NOX2 activation remains unresolved.

Phosphoinositide 3-kinase (PI3K) is also induced by NMDA receptor activation. ${ }^{21-23}$ PI3K phosphorylates the three position of hydroxyl groups on the inositol ring of specific phosphatidylinositol membrane phospholipids. ${ }^{24}$ PI3K activation engages prosurvival signaling pathways in many cell types, and in the central nervous system PI3K is also involved in neuronal plasticity. ${ }^{21,25}$ However, PI3K activation has also been associated with neuronal death in some settings, ${ }^{26,27}$ by mechanisms yet to be established.

\footnotetext{
${ }^{1}$ Department of Neurology, San Francisco Veterans Affairs Medical Center, University of California, San Francisco, CA, USA and ${ }^{2}$ INSERM U773, CRB3, Université Paris Diderot, Sorbonne Paris Cité, Laboratoire d'Excellence Inflamex, Faculté de Médecine, Site Xavier Bichat, Paris, France

${ }^{*}$ Corresponding author: AM Brennan-Minnella, Department of Neurology, San Francisco Veterans Affairs Medical Center, University of California, 4150 Clement St, San Francisco, CA 94121, USA. Tel: + 415750 2011; Fax: + 415750 2273; E-mail: angela.brennan@ucsf.edu

Keywords: Calcium; glutamate; NADPH oxidase; protein kinase $C$ zeta; protein kinase M

Abbreviations: NOX2, NADPH oxidase; PKC $\zeta$, protein kinase C (zeta); PKM, protein kinase M; PI3K, phosphoinositide 3-kinase; PI(3,4,5)P3, phosphatidylinositol (3,4,5)-triphosphate; PI(4,5)P2, phosphatidylinositol 4,5-bisphosphate; Eth, ethidium

Received 2.1.13; revised 12.2.13; accepted 18.2.13; Edited by A Verkhratsky
} 

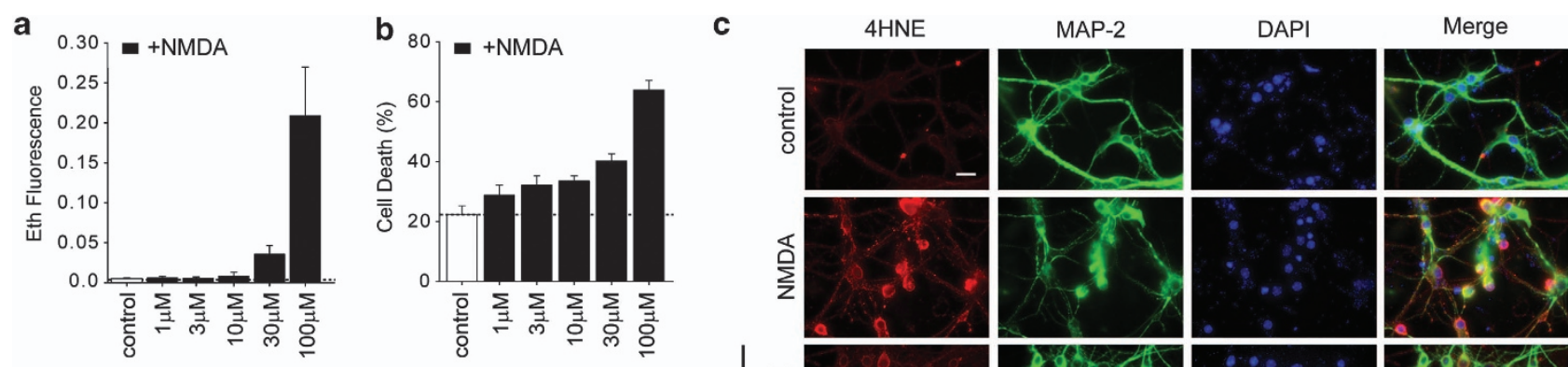
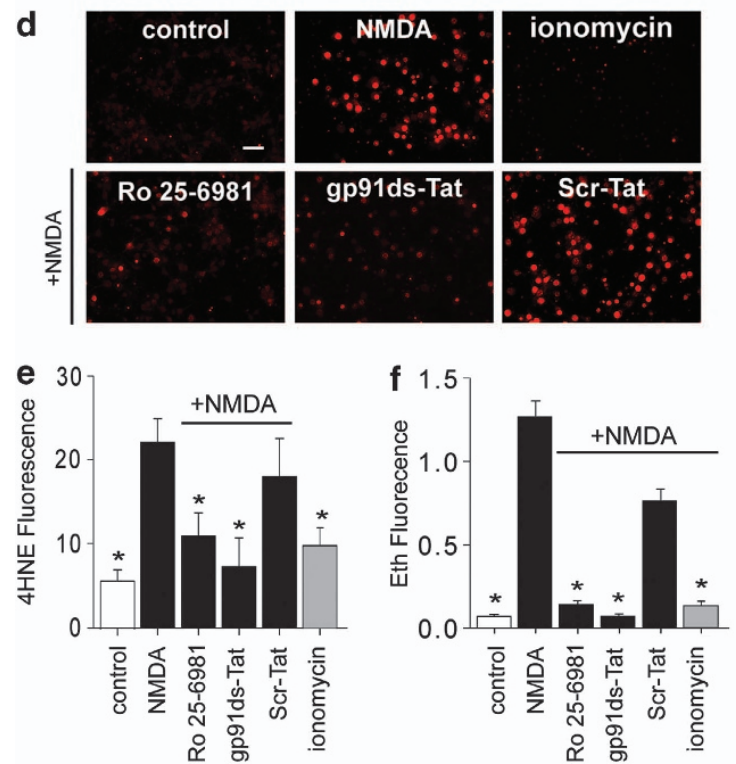
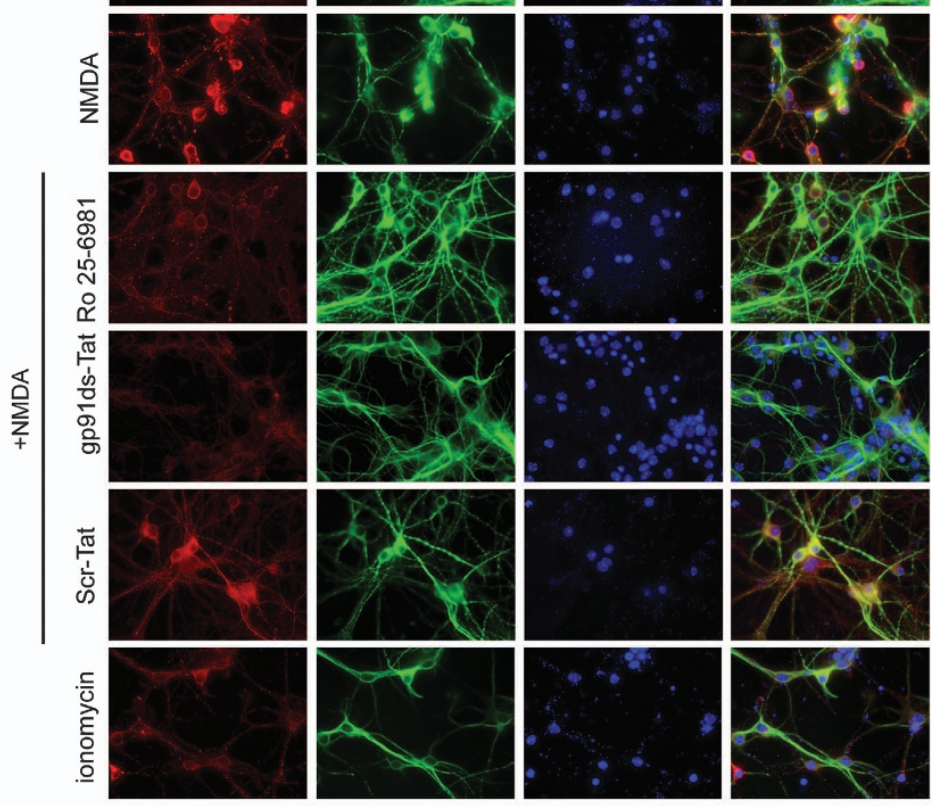

Figure 1 Excitotoxic neuronal superoxide production is mediated by NOX2 and triggered by NR2B-containing NMDA receptors. (a) NMDA-induced formation of oxidized dihydroethidium in cortical neurons is dose-dependent ${ }^{*} P<0.05$ versus control, $(n=3)$. All NMDA exposures are 30 min. (b) NMDA-induced neuronal death is also dosedependent, and roughly parallel to superoxide production ${ }^{*} P<0.05$ versus control, $n=3$ ). (c) Formation of $4 \mathrm{HNE}$ (red) in wild-type mouse cortical neurons after 30 min incubation with $100 \mu \mathrm{M}$ NMDA. Neuronal processes are identified by MAP-2 (green), and nuclei by 4',6-diamidino-2-phenylindole, DAPI (blue). NMDA-induced 4HNE formation was blocked by the Tat-conjugated NOX2 peptide inhibitor, gp91ds-Tat $(5 \mu \mathrm{M})$, but not by the scrambled sequence peptide (Scr-Tat; $5 \mu \mathrm{M})$. 4HNE formation was also blocked by the NR2B inhibitor, Ro 25-6981 $(0.5 \mu \mathrm{M})$, and not induced by ionomycin $(3 \mu \mathrm{M})$. Scale bar $20 \mu \mathrm{m}$. (d) Similar results were obtained using oxidized Eth species ( red) as a marker of superoxide formation. Scale bar $10 \mu \mathrm{m}$. ${ }^{*} P<0.01$ versus NMDA, $n=3$. (e) Quantification of $4 \mathrm{HNE}$ staining shown in (c). ${ }^{*} P<0.05$ versus NMDA, $n=3$. (f) Quantification of Eth fluorescence shown in (d). ${ }^{*} P<0.05$ versus NMDA, $n=3$

Here, we show that PI3K couples NMDA receptors to PKC $\zeta$ activation, NOX2 activation, and excitotoxic cell death. Inhibition of the PI3K signaling pathway blocks NOX2 activation, superoxide formation, and cell death, without blocking NMDA-induced calcium influx, cell swelling, or mitochondrial depolarization. These findings demonstrate a novel role for PI3K in regulating neuronal superoxide production, and suggest a shared signaling pathway underlying plasticity and excitotoxic death in the nervous system.

\section{Results}

NMDA-induced superoxide production requires activation of NOX2. Mouse cortical neuron cultures treated with NMDA exhibited dose-dependent superoxide formation and cell death (Figures 1a and b). These neurons exhibited characteristic features of excitotoxicity: intracellular calcium elevation, cell swelling, superoxide formation, mitochondrial depolarization, and subsequent cell death (Figures 1 and 3).
Superoxide production was assessed using two independent methods; formation of 4-hydroxynonenal (4HNE) from native lipids, ${ }^{28}$ and formation of oxidized ethidium species (Eth) from dihydroethidium ${ }^{29,30}$ (Figures 1c-f). Formation of both $4 \mathrm{HNE}$ and Eth were blocked in cultures treated with a peptide inhibitor of NOX2 assembly, gp91ds-Tat. ${ }^{31}$ (Figures 1c-f), thus confirming that these outcome measures are detecting superoxide in these studies. NMDA-induced superoxide production was similarly absent in cultures prepared from $\mathrm{p} 47^{\text {phox - I- }}$ mice, which are unable to form a functional NOX2 complex. ${ }^{19}$ However, when $\mathrm{p} 47^{\text {phox }}$ expression was reconstituted in these cultures by transfection, both NMDA-induced superoxide production and cell death were detected in the neighborhood of the transfected cells (Figure 2). The intracellular superoxide detection and cell death in these neighboring cells were negated by the addition of superoxide dismutase in the medium (Figure 2d), further confirming that the superoxide produced enters the extracellular space. ${ }^{15}$ 
a
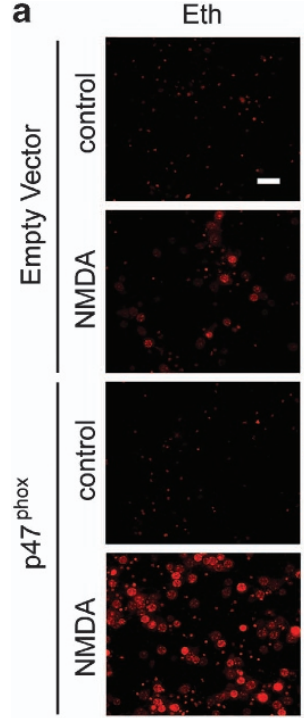

GFP
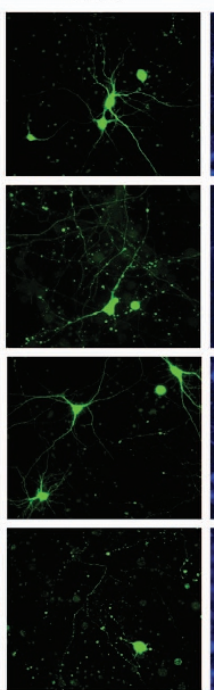

C
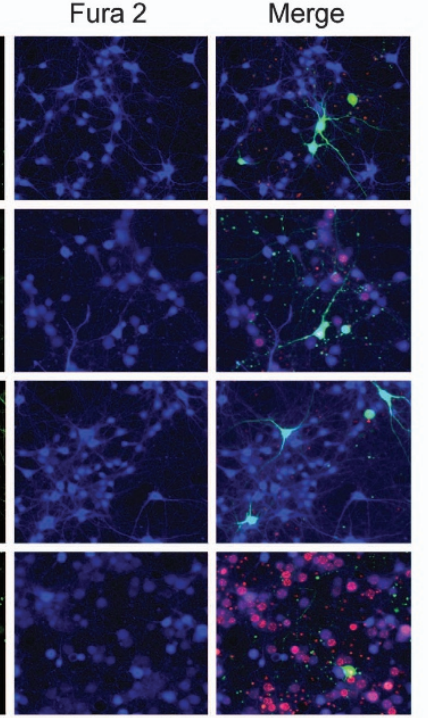

b

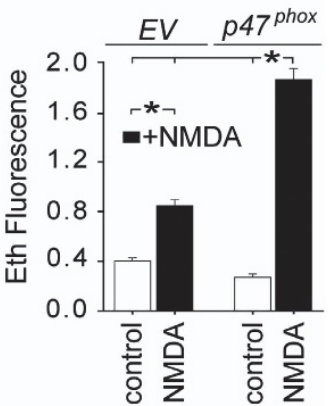

d

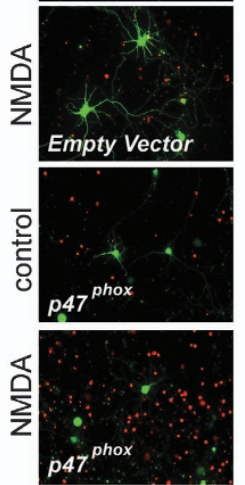

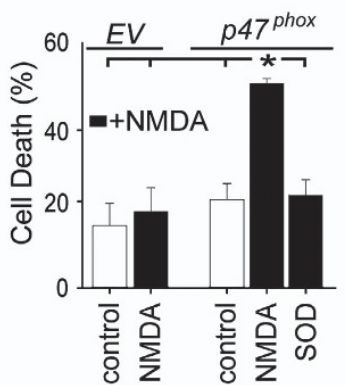

Figure 2 NOX2-competent neurons produce oxidative stress and cell death in neighboring neurons after NMDA exposure. Neuronal cultures were prepared from p47 $7^{\text {phox }}$ deficient (NOX2-incompetent) mice and transfected with p47 $7^{\text {phox }}$-GFP (p47 ${ }^{\text {phox }}$, green) to reconstitute NOX2 function in a subset of the neurons. Control cultures were transfected with the GFP tag alone (empty vector; green) (a). Oxidized Eth species (red) in neurons treated with or without $100 \mu \mathrm{M}$ NMDA. Neuronal processes are identified by Fura-2 (blue). Scale bar $=10 \mu \mathrm{m}$. (b) Quantification of Eth-positive neurons. EV, transfected with empty vector (GFP only), p47 $7^{\text {phox }}$, transfected with GFP-tagged p47 $7^{\text {phox }}$. ${ }^{\star} P<0.01, n=3$. (c) Dead neurons identified by propidium iodide staining (red) in neuronal cultures prepared from $p 47^{\text {phox }}$-deficient mice transfected with either GFP alone (empty vector; green) or p47 ${ }^{\text {phox }}$-GFP (p47 $7^{\text {phox }}$, green) and treated for 30 min with $100 \mu \mathrm{M}$ NMDA. Scale bar $=10 \mu \mathrm{m}$. (d) Quantification of neuronal death. Where indicated neurons were treated with $100 \mu \mathrm{M}$ NMDA together with $100 \mathrm{U}$ superoxide dismutase- $1,{ }^{*} P<0.01$ versus NMDA, $n=3$

\section{NMDA-induced NOX2 activation requires calcium entry} through NR2B-containing NMDA receptors. NMDA receptors are heterodimers that typically contain an NR1 subunit paired with either an NR2A or NR2B subunit, of which the NR2B subunit has been functionally linked to cell death. ${ }^{32,33}$ To determine whether NR2B subunits are involved in superoxide production, cultures were treated with NMDA in the presence of the NR2B-selective antagonist, Ro $25-6981 .^{34}$ Ro 25-6981 blocked the superoxide production (Figure 1) and cell death (Figures $3 a$ and b) otherwise produced by NMDA.

Calcium influx is required for both NMDA-induced neuronal death and NOX2 activation. 5,35 To determine whether the calcium influx route is an important factor, we compared the effects of NMDA and the calcium ionophore ionomycin, using ionomycin at concentrations that generated a rate and magnitude of calcium elevation comparable to that induced by $100 \mu \mathrm{M}$ NMDA. Under these conditions, both NMDA and ionomycin-induced mitochondrial membrane depolarization, but only NMDA-induced superoxide production and cell death (Figure 3). In both conditions, the extent of mitochondrial membrane potential was incomplete relative to that caused by FCCP. Intracellular calcium measurements were also performed using the low affinity calcium indicator Fura-FF to reduce the possibility that non-linear dye responses, averaging of heterogeneous intracellular compartments, zinc 
a
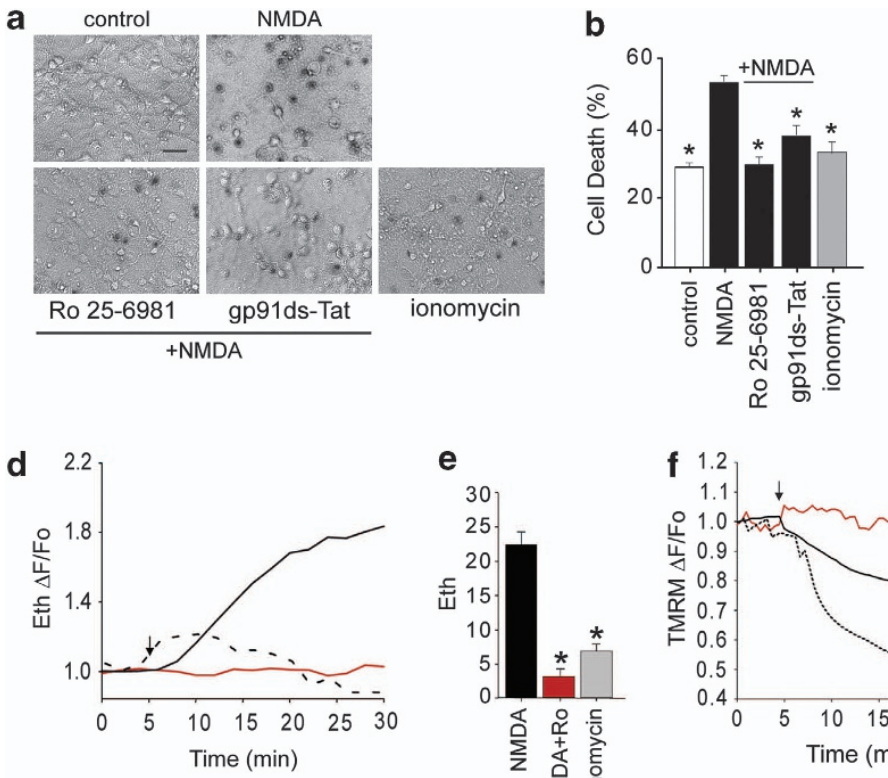

e

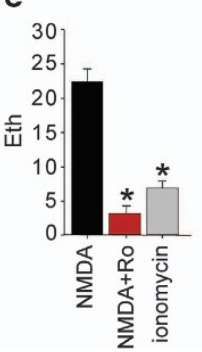

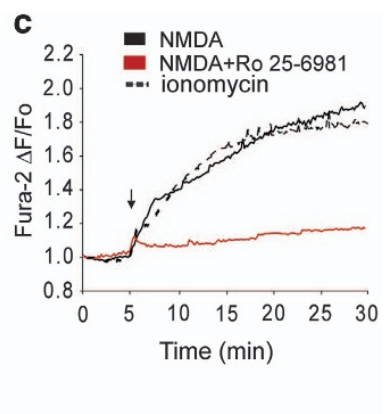

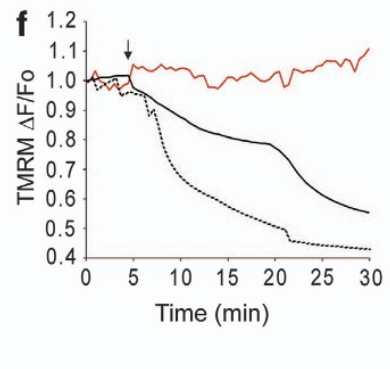

g

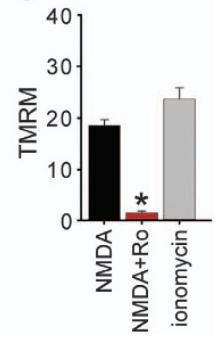

Figure 3 Excitotoxic neuronal death is mediated by NOX2 and triggered by NR2B-containing NMDA receptors. (a) Trypan blue staining of dead neurons $24 \mathrm{~h}$ after 30 -min exposure to $100 \mu \mathrm{M}$ NMDA, conditions as in Figure 1C. Scale bar $20 \mu \mathrm{m}$. (b) Quantified cell death. ${ }^{*} P<0.05$ versus NMDA, $n=3$. (c) Representative (of $n=4$ ) real-time calcium transients measured with Fura-2. Drugs were added after $5 \mathrm{~min}$ of baseline recording (arrow). (d) Representative trace of superoxide production as measured by Eth fluorescence in the same neurons as (c). Note Eth increase with NMDA but not ionomycin. (e) Quantified results; ${ }^{*} P<0.01$ versus NMDA, $n=3$. (f) Representative traces of mitochondrial membrane potential, as evaluated using TMRM fluorescence in a separate set of experiments. Note mitochondrial depolarization with both NMDA and ionomycin. (g) Quantified results; ${ }^{*} P<0.01$ versus NMDA, $n=3$

binding, or calcium saturation of the high-affinity Fura-2 dye were masking differences in calcium elevations produced by NMDA and ionomycin. ${ }^{36,37}$ The studies using high- and lowaffinity calcium dyes gave similar results (Supplementary Figure 1).

Of note, ionomycin-induced superoxide production was observed when ionomycin was used at a concentration $(10 \mu \mathrm{M})$ that produced far higher calcium elevations than produced by NMDA (Supplementary Figure 2). However, the superoxide production induced by $10 \mu \mathrm{M}$ ionomycin was not diminished by NOX2 inhibition, consistent with the report that very high calcium elevations can induce neuronal superoxide production by a source other than NOX2. ${ }^{38}$

NMDA-induced NOX2 activation requires PI3K activation. NOX2 activation requires phosphorylation of its $p 47^{\text {phox }}$ subunit, a process performed by different PKC isoforms in different cell types. ${ }^{19}$ Our finding that ionomycin-induced calcium elevations do not activate neuronal NOX2 suggests the involvement of an 'atypical' PKC isoform, activated by signals other than calcium elevation. $\mathrm{PKC} \zeta$ is an atypical PKC previously linked to neuronal NOX2 activation, ${ }^{5}$ and $\mathrm{PKC} \zeta$ is activated by $\mathrm{PI} 3 \mathrm{~K} .{ }^{20}$ Given that PI3K activation can be triggered by calcium entry specifically through NMDA receptors, ${ }^{22,39}$ we evaluated the role of PI3K in NMDAinduced NOX2 activation. Neurons exposed to NMDA with the PI3K inhibitor, wortmannin, showed greatly attenuated superoxide formation and cell death (Figures 4a-d). Wortmannin did not, however, block other aspects of NMDA receptor activation; intracellular calcium elevation, mitochondrial depolarization, or cell swelling (Figures $4 \mathrm{e}-\mathrm{h}$ ).
To confirm that the wortmannin effect on NOX2 activation is caused specifically by PI3K inhibition, we supplied wortmannin-treated cultures with the phosphatidylinositol $(3,4,5)$ triphosphate $(\mathrm{PI}(3,4,5) \mathrm{P} 3)$ product of PI3K using a BODIPYtagged lipid carrier. ${ }^{40}$ The exogenous $\mathrm{PI}(3,4,5) \mathrm{P} 3$ did not itself induce superoxide production, but did restore NMDA-induced superoxide production in the wortmannin-treated cultures (Figures $5 \mathrm{a}$ and b). By contrast, treatment with the PI3K substrate, phosphatidylinositol 4,5-bisphosphate ( $\mathrm{PI}(4,5) \mathrm{P} 2)$, did not reconstitute superoxide production.

PI3K activates neuronal NOX2 by activating PKC $\zeta$. If $\mathrm{PI} 3 \mathrm{~K}$ functions to activate $\mathrm{PKC} \zeta$ in this signaling pathway, then the effects of PI3K inhibition should be circumvented in neurons expressing a constitutively active $\mathrm{PKC} \zeta$. We tested this idea by transfecting neurons with protein kinase $M$ (PKM), a truncated, constitutively active form of $\mathrm{PKC} \zeta .41,42$ PKM expression did not induce superoxide production in the absence of NMDA, but it did restore NMDA-induced superoxide production in the wortmannin-treated cultures (Figures $5 c$ and d). This observation confirms both that $P K C \zeta$ activity is essential in this pathway, and that $\mathrm{PKC} \zeta$ is activated by PI3K in the setting of NMDA receptor activation.

$\mathrm{PI} 3 \mathrm{~K}$ is also involved in the pleiotropic Akt phosphorylation pathway. ${ }^{43}$ Immunoblots confirmed that wortmannin suppressed Akt phosphorylation in the neuron cultures. By contrast, inhibition of Akt function with triciribine showed no effect on NMDA-induced superoxide formation (Supplementary Figure 3), thus excluding a role for Akt in this process.

PI3K inhibition prevents phosphorylation of PKC $\zeta$ and $\mathrm{p} 47^{\text {phox }}$. Although phosphorylation of ser328 on $\mathrm{p} 47^{\text {phox }}$ is 
a
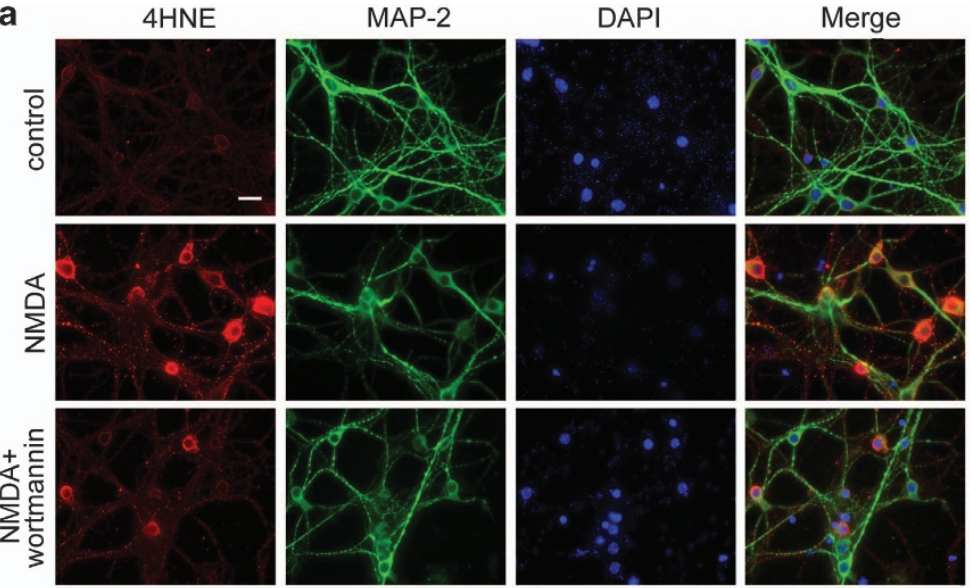

b

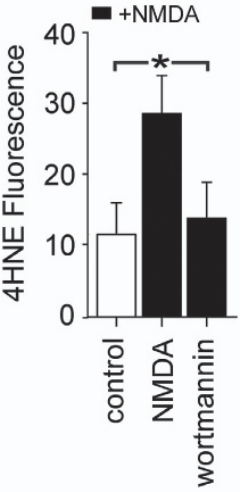

C
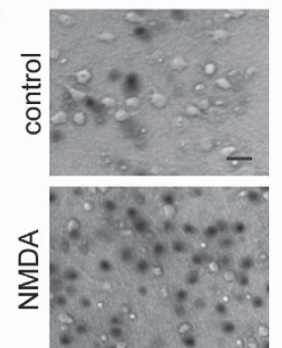

d
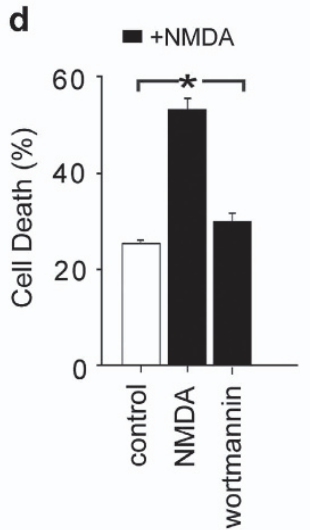

e

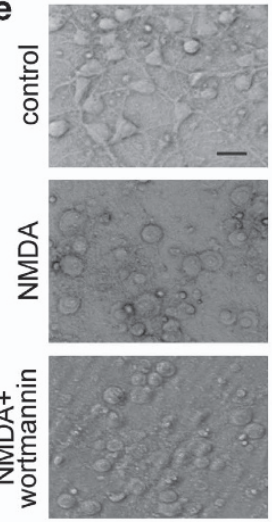

f

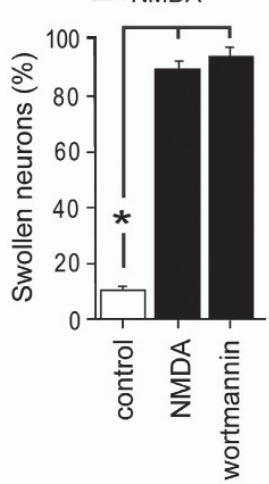

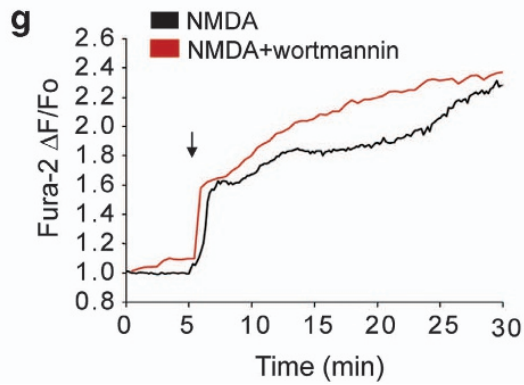

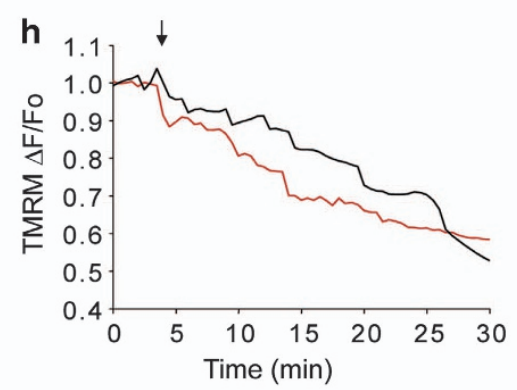

Figure 4 PI3K inhibition blocks NMDA-induced superoxide production and cell death. (a) Formation of 4HNE (red) in neurons after 30 min exposures to $100 \mu \mathrm{M}$ NMDA. Neuronal processes are identified by MAP-2 (green), and nuclei by DAPI (blue). 4HNE formation was blocked in cultures treated with $10 \mu \mathrm{M}$ wortmannin. Scale bar is $20 \mu \mathrm{m}$. (b) Quantification of $4 \mathrm{HNE}$ formation. ${ }^{*} P<0.05$ versus NMDA, $n=3$. (c) Phase contrast images of trypan blue staining shows that wortmannin prevents NMDA-induced neuronal death. (d) Quantification of neuronal death. ${ }^{*} P<0.05$ versus NMDA, $n=3$. (e) Phase contrast images show cell swelling following NMDA application is not blocked by wortmannin. Scale bar is $20 \mu \mathrm{m}$. (f) Quantification of neuronal swelling. ${ }^{*} P<0.01$ versus control, $n=3$. (g and $\left.\mathbf{h}\right)$ Wortmannin had no significant effect on NMDA-induced calcium elevations as measured by Fura-2, or on mitochondrial membrane potential as measured by TMRM. Representative of $n=4$

required for its assembly with other NOX2 complex proteins, ${ }^{20}$ it is possible that $\mathrm{PKC} \zeta$ activation could lead to NOX2 activation by a route independent of $\mathrm{p} 47^{\text {phox }}$. Immunostaining for phospho-ser328 p47 $7^{\text {phox }}$ confirmed that phosphorylation at this site is induced by NMDA, and not ionomycin (Figures $6 \mathrm{a}$ and $\mathrm{b}$ ). The phosphorylation was blocked by both wortmannin and a Tat-conjugated $\mathrm{PKC} \zeta$ inhibitory peptide previously shown to prevent neuronal NOX2 activation, ${ }^{5}$ thus placing this event downstream of $\mathrm{PI} K \mathrm{~K}$ and $\mathrm{PKC} \zeta$. Evaluation of $\mathrm{PKC} \zeta$ phosphorylation showed a parallel result: NMDA (but not ionomycin)-induced phosphorylation of PKC $\zeta$ at the $\operatorname{Thr}(410 / 403)$ residue(s) required for its activation, ${ }^{44}$ and this phosphorylation was also blocked by wortmannin (Figures 6c and d).

\section{Discussion}

Superoxide production is a requisite event in the excitotoxic cell death process triggered by NMDA receptor activation, $6,7,12$ and superoxide is a major source of oxidative stress in brain ischemia and other neurological disorders. ${ }^{16-18}$ Results presented here show that NMDA induces superoxide 
a
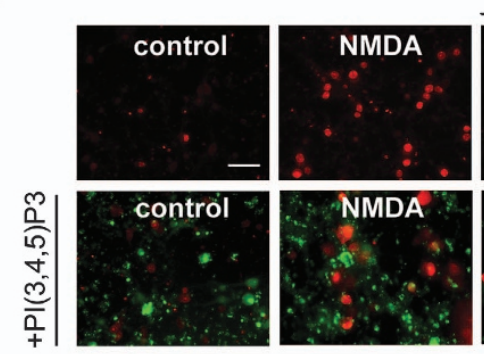

C
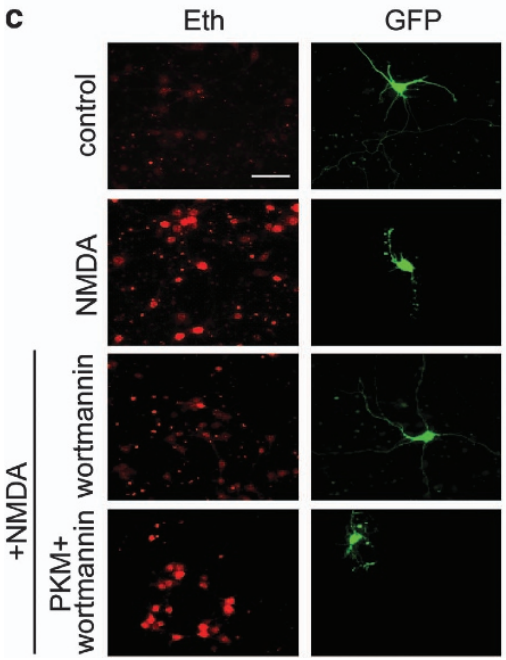

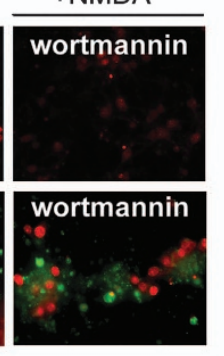

+ NMDA

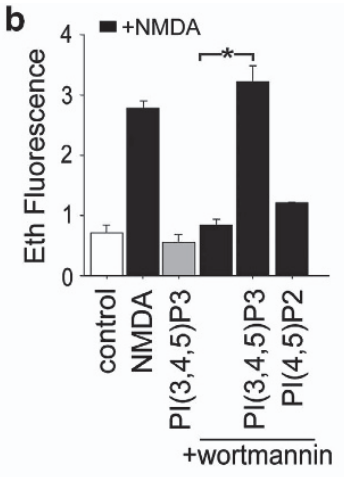

d
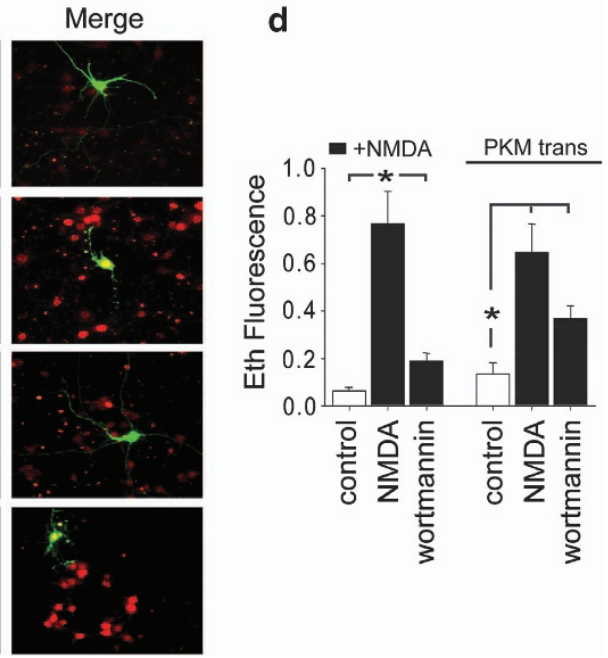

Figure 5 Lipid products of PI3K and transfection with constitutively active PKC $\zeta$ (PKM) reverse wortmannin inhibition of NMDA-induced superoxide formation. (a) Formation of oxidized dihydroethidium (red) in cortical neurons treated with NMDA is suppressed in cultures cotreated with wortmannin. Where indicated, neurons were also treated with the PI3K product, $\mathrm{PI}(3,4,5) \mathrm{P} 3$ coupled to a cell permeable carrier tagged with BODIPY (green). The exogenously supplied PI(3,4,5)P3 restored NMDAinduced superoxide formation in the presence of wortmannin, but the PI3K substrate PI(4,5)P2 did not. Scale bar $=20 \mu \mathrm{m}$. (b) Quantification of Eth-positive neurons. ${ }^{*} P<0.01$ versus control, $n=3-6$. (c) Formation of Eth (red) in neurons transfected with GFP-tagged PKM (green). Neurons were treated with NMDA (100 $\mu$ M) alone or with wortmannin $(10 \mu \mathrm{M})$. Scale bar $20 \mu \mathrm{m}$. (d) Quantification of Eth-positive neurons. ${ }^{*} P<0.05$ versus control; $n=4$

production through a signaling pathway involving PI3K. Calcium influx through NR2B-containing NMDA receptors is coupled by $\mathrm{PI} 3 \mathrm{~K}$ to the activation of $\mathrm{PKC} \zeta$, with resultant phosphorylation of $\mathrm{p} 47^{\text {phox }}$ (Figure 7). Phosphorylation of $\mathrm{p} 47^{\text {phox }}$ leads to assembly of an activated NOX2 complex and extracellular release of superoxide. Perturbations in this pathway have the potential to either increase or decrease superoxide production in response to NMDA receptor activation, and may thus be relevant to the many neurological disorders, in which excitotoxic cell death occurs.

Calcium influx has long been established as a requisite event in excitotoxicity, ${ }^{35}$ but it has been difficult to resolve whether the route of calcium influx is important in this process. ${ }^{33,38,45}$ Tymianski and colleagues $^{8,46}$ showed that NMDA-induced nitric oxide production requires calcium influx specifically through NMDA receptors. Similarly, in the pathway described here, calcium influx gated by NR2B-containing NMDA receptors leads to NOX2 activation and cell death, whereas ionomycin-induced calcium elevations of comparable magnitude do not. These results demonstrate that calcium influx gated specifically by NMDA receptors can trigger excitotoxic death, and they are also consistent with recent studies implicating NR2B-containing receptors as selectively responsible for excitotoxic neuronal death. ${ }^{33}$ On the other hand, our findings that high intracellular calcium elevations induced by ionomycin trigger superoxide production and cell death by a mechanism independent of NOX2 (presumably from mitochondria) illustrates that other routes of calcium-mediated neuronal death may also be contributory.

Ligand binding to NR2B-containing NMDA receptors activates PI3K by mechanisms involving binding between $\mathrm{NR} 2 \mathrm{~B}$, the adapter protein APPL1, and the p85 regulatory subunit of PI3K. ${ }^{39,47,48}$ Our findings show that NR2B-containing NMDA receptors elicit NOX2 activation by a mechanism that is blocked by the PI3K inhibitor, wortmannin. Wortmannin may have effects other than PI3K inhibition, but three lines of evidence argue that the effects of wortmannin on NMDAinduced NOX2 activation are due specifically to PI3K inhibition. First, events identified as downstream of PI3K were blocked by wortmannin (AKT phosphorylation, PKC $\zeta$ phosphorylation, $\mathrm{p} 47^{\text {phox }}$ phosphorylation, superoxide production, and cell death), whereas those occurring upstream or independent of PI3K were not (calcium influx, mitochondrial depolarization, and cell swelling); second, the inhibitory effect 
a

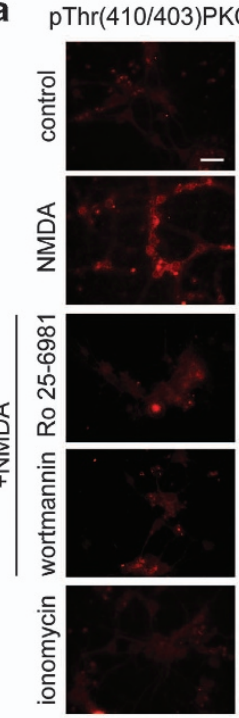

Merge

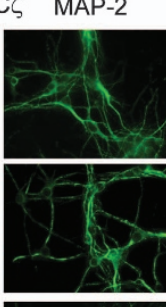

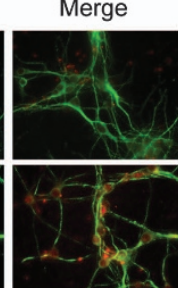
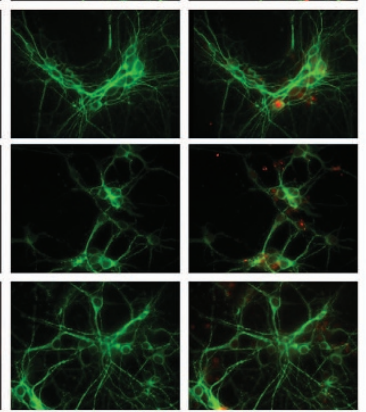

C

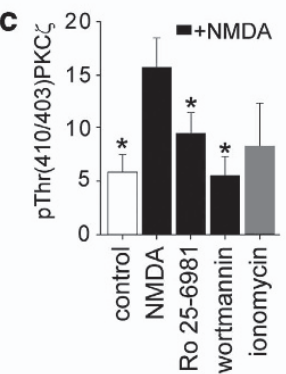

b
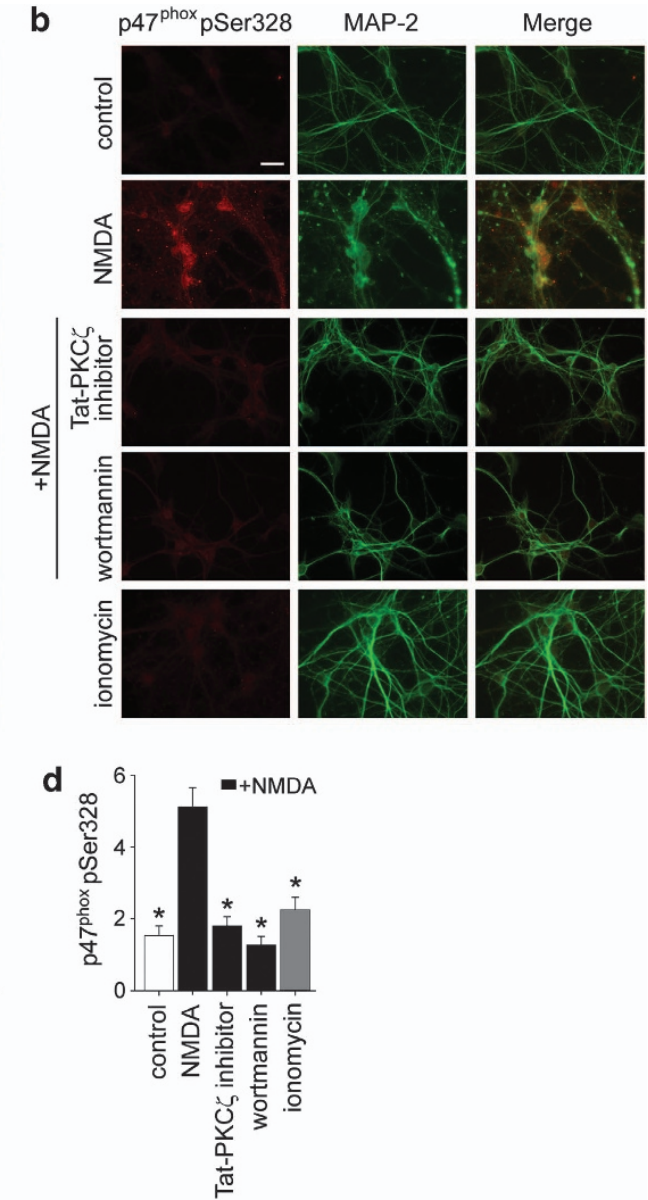

Figure 6 NMDA induces PI3K-dependent phosphorylation of $\mathrm{PKC} \zeta$, and $\mathrm{PKC} \zeta$-dependent phosphorylation of p47 ${ }^{\text {phox }}$. (a) Immunostaining for phospho-PKC $\zeta$ (phosphorylated at Thr410/403; red). Neuronal processes are identified with antibody to MAP-2 (green). PKC $\zeta$ phosphorylation was induced by NMDA, but not by the calcium ionophore ionomycin. PKC $\zeta$ phosphorylation was blocked by both the NR2B inhibitor RO 25-6981 and the PI3K inhibitor wortmannin. Conditions as in Figure 1a. (b) Immunostaining for phospho-p47 $7^{\text {phox }}$ (phosphorylated at Ser328; red). Phosphorylation was induced by NMDA, but not by ionomycin. p47 $7^{\text {phox }}$ phosphorylation was blocked by both wortmannin and a Tat-conjugated peptide inhibitor of PKC $\zeta$. Scale bars are $20 \mu \mathrm{m}$. (c and d) Quantification of immunostaining. ${ }^{*} P<0.05$ versus NMDA; $n=4$

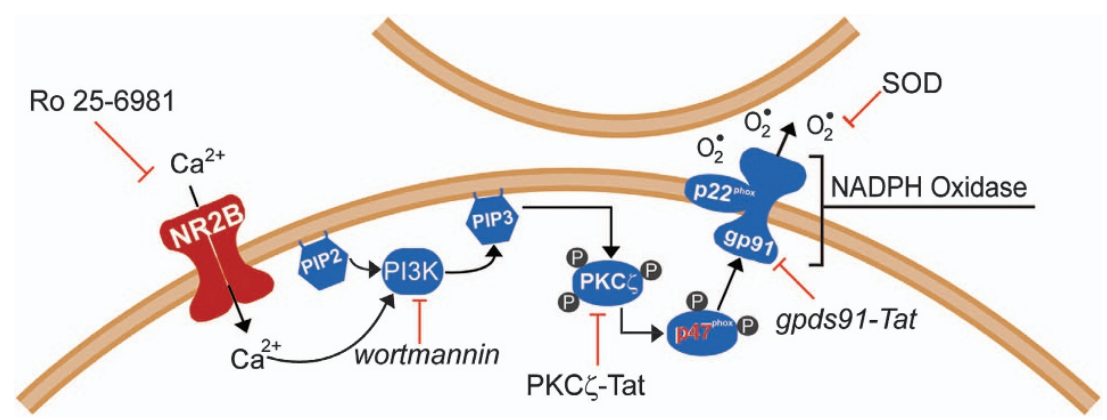

Figure 7 Signaling pathway linking NMDA receptor activation to NOX2 superoxide production. Calcium influx via NR2B-containing NMDA receptors induces PI3K to form $\mathrm{PI}(3,4,5) \mathrm{P} 3$. PI $(3,4,5) \mathrm{P} 3$ activates $\mathrm{PKC} \zeta$, which phosphorylates the $\mathrm{p} 47^{\text {phox }}$ organizing subunit of NOX2. Phosphorylated $\mathrm{p} 47^{\text {phox }}$ induces assembly of the active NOX2 complex at the cell surface and production of superoxide. Red lines indicate the targets of the probes used in these experiments

of wortmannin on superoxide formation was reversed by exogenous delivery of the $\mathrm{PI} 3 \mathrm{~K}$ product, $\mathrm{PI}(3,4,5) \mathrm{P} 3$; and third, the inhibitory effect of wortmannin on superoxide formation was similarly reversed in neurons transfected with $\mathrm{PKM}$, a constitutively active form of $\mathrm{PKC} \zeta$ that does not require PI3K activation. ${ }^{41,42}$
The organizing $\mathrm{p} 47^{\mathrm{phox}}$ subunit of NOX2 can be phosphorylated (activated) by $\mathrm{PKC} \zeta$. The role of $\mathrm{PKC} \zeta$ in this process was confirmed here using an inhibitory pseudosubtrate peptide. ${ }^{49}$ This peptide inhibitor can have off-target effects, ${ }^{50,51}$ but the role of PKC $\zeta$ in NMDA-induced $\mathrm{p} 47^{\text {phox }}$ phosphorylation is also demonstrated by the observation that 
transfection with a constitutively active form of $\mathrm{PKC} \zeta$ negates the effect of wortmannin. The mechanism by which PI3K activates $\mathrm{PKC} \zeta$ has not been resolved, but may involve either direct interaction between $\mathrm{PI}(3,4,5) \mathrm{P} 3$ with $\mathrm{PKC} \zeta{ }^{52}$ or an indirect effect mediated by $\mathrm{PI}(3,4,5) \mathrm{P} 3$ stimulation of PDK1 phosphorylation of PKC $\zeta .{ }^{53}$ Of note, neither exogenous $\mathrm{PI}(3,4,5) \mathrm{P} 3$ nor transfection with PKM induced superoxide formation in the absence of NMDA receptor stimulation (Figure 5b). This result is not unexpected, however, because activation of NOX2 requires not only the signaling pathway described here, but also $\mathrm{p} 47^{\text {phox }}$ phosphorylation at additional sites and the concomitant activation of both rac1 and phospholipase $\mathrm{A} 2 .^{54}$

The role of $\mathrm{PI} 3 \mathrm{~K}$ in excitotoxicity and oxidative stress identified here contrasts with the well-established prosurvival effects of PI3K mediated by the Akt pathway. ${ }^{43}$ Previous work has demonstrated that prosurvival pathways required for neuroprotection in developing neurons is dependent on NMDA-induced activation of $\mathrm{PI} 3 \mathrm{~K},{ }^{55,56}$ and selective disruption of NMDA-induced Akt signaling results in widespread apoptosis. ${ }^{39}$ The contrasting toxic and trophic roles of NMDA-induced PI3K activity may be reconciled, however, given that both PI3K and superoxide have also been independently identified as mediators of intercellular signaling and synaptic plasticity in the nervous system. ${ }^{21,25,57}$ The cytotoxic, PI3K-dependent superoxide production that occurs during sustained NMDA receptor activation may thus be an exaggerated, pathological manifestation of normal intercellular signaling.

\section{Materials and Methods}

Studies were performed in accordance with protocols approved by the San Francisco Veterans Affairs Medical Center animal studies subcommittee. Wild-type and $\mathrm{p} 47^{\text {phox -1- }}$ mice on the C57/BI6 background were obtained from the Jackson Laboratories (Bar Harbor, ME, USA). The p4 $7^{\text {phox - l- }}$ mice were maintained as homozygotes with the use of fresh breeder stock, fully back-crossed to wt C57/BI6 mice, after every eight generations. Cell culture reagents were obtained from Mediatech (Manassas, VA, USA), and all other reagents were obtained from SigmaAldrich (St Louis, MO, USA) except where noted. Data analyses for all studies were performed by observers blinded to the experimental conditions.

Neuron cultures. Cultures were prepared from the cortices of embryonic day 15 mice and plated in 24-well culture plates or poly-D-lysine coated glass coverslips. ${ }^{58}$ After 1 day in culture, $10 \mu \mathrm{M}$ cytosine arabinoside was added for $24 \mathrm{~h}$ to prevent glial proliferation. The neurons were subsequently maintained with serum-free NeuroBasal medium (Gibco, Grand Island, NY, USA) containing $5 \mathrm{mM}$ glucose, and used at day 10-12 in vitro. These cultures contain $>95 \%$ neurons and no detectable microglia. ${ }^{58}$ Experiments were initiated by exchanging the culture medium with a low-magnesium balanced salt solution (BSS): $1.2 \mathrm{mM}$ $\mathrm{CaCl}_{2}, 0.4 \mathrm{mM} \mathrm{MgSO}_{4}, 5.3 \mathrm{mM} \mathrm{KCl}, 0.4 \mathrm{mM} \mathrm{KH_{2 }} \mathrm{PO}_{4}, 137 \mathrm{mM} \mathrm{NaCl}_{2}, 0.3 \mathrm{mM}$ $\mathrm{NaHPO}_{4}, 5 \mathrm{mM}$ glucose, and $10 \mathrm{mM}$ 1,4-piperazinediethanesulfonate buffer, $\mathrm{pH}$ 7.2. Drugs were added from concentrated stocks $10 \mathrm{~min}$ before the addition of NMDA.

Immunostaining. Formaldehyde-fixed cultures were immunostained as described previously, ${ }^{5,58}$ using rabbit antibody to 4-hydroxynonenal (Alpha Diagnostics, San Antonio, TX, USA; 1:500), rabbit antibody to phosphoPKC $\zeta / \lambda$ (Thr410/403; Cell Signaling, Danvers, MA, USA; 1:100), and mouse antibody to microtubule-associated protein 2 (Chemicon, Temecula, CA, USA; 1:500). Antibody binding was visualized with Alexa Fluor 488-conjugated antimouse IgG or Texas Red 594-conjugated anti-rabbit IgG (Invitrogen, Grand Island, NY, USA). Antibodies to detect to phospho-p47 $7^{\text {phox }}$ (Ser 328) were a generous gift from from J El Benna, Paris. For studies with this antibody, fixation was performed with $0.5 \%$ glutaraldehyde followed by borohydride reduction. Images were obtained using confocal fluorescence microscopy using step-wise $1 \mu \mathrm{M}$ z-stack sampling. In some cases cell nuclei were also identified for fluorescence imaging by incubation with $1 \mu \mathrm{M} \mathrm{4}$ ',6-diamidino-2-phenylindole after antibody removal. For quantification of neuronal $4 \mathrm{HNE}$, phospho-PKC $/ \lambda$, and phospho-p $47^{\text {phox }}$ immunostaining, the mean fluorescence intensity was obtained over the area defined by MAP-2 fluorescence. Neurons were analyzed in three randomly chosen optical fields from each of four coverslips per experiment, with $>100$ neurons per coverslip, for a total of 400-500 neurons per ' $n$ '.

Western blots. Cells were lysed in $50 \mathrm{mM}$ Tris-HCl, pH 7.4, $100 \mathrm{mM} \mathrm{NaCl}, 1 \%$ SDS, and protease inhibitor (Roche, Pleasanton, CA, USA). Protein homogenates were sonicated, diluted in Laemmli buffer, and eletrophoretically separated on SDS-PAGE gels (Bio-Rad, Hercules, CA, USA). Proteins were transferred to PVDF membranes and incubated with antibodies diluted in Tris buffer saline containing $0.1 \%$ Tween-20 and $5 \%$ milk protein. Antibodies used were antiphospho-Bad(Ser99) (Millipore, Billerica, MA, USA), anti-phospho-Akt(Ser473) (Cell Signaling), and anti-Akt (Cell Signaling). After rinsing, membranes were incubated with secondary antibodies coupled to horseradish peroxidase (Vector Laboratories, Burlingame, CA, USA), and antibody binding was detected using the ECL or ECL Plus substrate (GE Healthcare, Pittsburgh, PA, USA).

Peptide inhibitors. Tat-conjugated peptide inhibitors targeting $\mathrm{PKC} \zeta$ and gp91 and scrambled sequence control peptide were commercially generated (CPC Scientific, Sunnyvale, CA, USA), using amino acid sequences described. ${ }^{31,49}$

Eth imaging of superoxide production. Five micromolars of dihydroethidium (Invitrogen) was added to cultures $10 \mathrm{~min}$ before the start of the experiment, and maintained throughout. The cultures were photographed at the specified time points with a fluorescence microscope (Axiovert $40 \mathrm{CFL}$, Zeiss, Thornwood, NY, USA) using 510-550 nm excitation and >580 nm emission, and with transmitted light phase contrast. The fluorescence of oxidized Eth species was measured in three randomly chosen optical fields from each culture well and calculated as Eth fluorescence area $\times$ intensity, normalized to cell number. The cell number was counted in the corresponding phase contrast images of each optical field. In some cases, neurons were also identified under fluorescence imaging using Fura-2 in non-ratiometric mode. Measurements were made in four wells per experiment, with $>100$ neurons per well for a total of $400-$ 500 neurons per ' $n$ '. For real-time imaging, images were acquired at $1 \mathrm{~min}$ intervals ( $40 \mathrm{~ms}$ exposure). The change in raw fluorescence for each neuron within the field of view was then normalized to baseline fluorescence, and these data were quantified by integrating the change from baseline over the 30 -min observation intervals. Each ' $n$ ' value was the calculated mean response of 8-12 neurons per coverslip. Superoxide (or a superoxide metabolite) was confirmed as the reactive oxidant by negation of Eth formation in the studies where NOX2 activity was blocked.

Intracellular calcium and mitochondrial membrane potential imaging. Neurons were loaded for 30 min with either $4 \mu \mathrm{M}$ Fura-2 AM or FuraFF AM (Molecular Probes, Grand Island, NY, USA) and washed once with BSS before imaging. When simultaneous detection of mitochondrial membrane potential was conducted, Fura was removed and exchanged for BSS containing $1 \mathrm{nM}$ TMRM (Molecular Probes) for $20 \mathrm{~min}$ at $37^{\circ} \mathrm{C}$, and maintained in $1 \mathrm{nM}$ TMRM throughout recordings. Images were acquired at $30 \mathrm{~s}$ intervals, using excitation that alternated between 340 and $380 \mathrm{~nm}$ (emission $>510 \mathrm{~nm}$ ) for Fura2 (or Fura-FF), and $510-550 \mathrm{~nm}$ excitation (>580 nm emission) for TMRM. Calcium changes levels were expressed as change in the $340 / 380 \mathrm{~nm}$ signal ratio relative to baseline fluorescence $\left(\Delta \mathrm{F} / \mathrm{F}_{0}\right)$, and quantified by integrating the change over baseline over 30-min observation intervals. Regions of interests for TMRM fluorescence were drawn around populations of mitochondria. In a subset of experiments, application of FCCP $(3 \mu \mathrm{M})$ caused an increase in cytosolic TMRM fluorescence immediately adjacent to depolarizing mitochondria, thus confirming that observed reductions in the TMRM fluorescence were due to TMRM efflux from the mitochondria.

Plasmids and neuronal transfections. Plasmid coding for $p 47^{\text {phox }}$-GFP was a generous gift from Dr. Lance Terada, University of Texas Southwestern, and the corresponding empty vector was eGFP-N1 (BD Bioscience, San Jose, CA, USA). PKM (Genebank accession NM_001039079) was amplified with primers 
$5^{\prime}$-tgcgaattcaatggattctgtcatgccttcc- $3^{\prime}$ and $5^{\prime}$-attgtcgactcacacggactcctcagcag- $3^{\prime}$ from adult mouse brain $\mathrm{CDNA}$, digested with $\mathrm{EcOR} I$ and Sal I, and ligated into the pIRES-hr-GFP (Agilent, Santa Clara, CA, USA) vector. Sequencing confirmed that the coding frame of PKM was fused with a 3xFlag tag and followed by a stop codon and an IRES-hr-GFP codon. Expression of the expected PKM-IRES-hrGFP in transfected HEK293 cells was confirmed by western blots probed with anti-flag antibody. Neuronal transfections were performed on culture day 6 or 7 using Lipofectamine 2000 (Invitrogen).

Intracellular delivery of phospholipids. $\mathrm{PI}(3,4,5) \mathrm{P} 3, \mathrm{PI}(4,5) \mathrm{P} 2$ and the BODIPY-labeled cell-permeable carrier were commercially purchased (Echelon, Salt Lake City, UT, USA). The phospholipids and the carrier were reconstituted at $1 \mathrm{mM}$ in BSS, combined at a 1:1 molar ratio for $10 \mathrm{~min}$, and added to culture wells at a final concentration of $40 \mu \mathrm{M}$.

Cell swelling. Cell morphology was evaluated in phase contrast images of unfixed cells. Neuronal soma were scored as swollen if they lost their normal angulated shape and assumed a rounded morphology. Neurons were evaluated in three randomly chosen fields in a minimum of four wells per plate for each independent experiment. Results from each experiment were expressed as the percent of neurons that had a swollen morphology.

Cell death. Dead neurons were identified by staining with either trypan blue or in studies using fluorescence markers, with propidium iodide, $24 \mathrm{~h}$ after NMDA exposures. ${ }^{59}$ Live and dead neurons were counted in three randomly chosen fields in a minimum of four wells per plate, and results of each experiment were expressed as the percent of neurons that were dead.

Statistical analyses. In all cases, the ' $n$ ' values denote the number of independent experiments, each using neurons prepared from different mice. Each independent experiment contained triplicate culture wells or coverslips of each study condition, with measurements obtained from at least 200 neurons in each well from a 24-well plate or an average of 10 neurons per each coverslip. Data are expressed as means \pm S.E.M. and assessed using one-way ANOVA followed by the Tukey-Kramer test where multiple groups are compared against one another, or Dunnett's test where multiple groups are compared against a common control group.

\section{Conflict of Interest}

The authors declare no conflict of interest.

Acknowledgements. We thank J-Y Ahn, SM Massa, and S Finkbeiner for helpful discussions and $\mathrm{C}$ Hefner for technical assistance. This work was supported by funding from the US National Institutes of Health (NS041421) and by the US Department of Veterans Affairs. AMB-M designed and performed most of the experiments and prepared the initial manuscript. RAS conceived the project and prepared the final manuscript. The authors declare no competing financial interests.

1. Choi DW. Glutamate neurotoxicity and diseases of the nervous system. Neuron 1988; 1 $623-634$

2. Meldrum BS. Excitotoxicity and selective neuronal loss in epilepsy. Brain Pathol 1993; 3 405-412.

3. Rothstein JD. Current hypotheses for the underlying biology of amyotrophic latera sclerosis. Ann Neurol 2009; 65(Suppl 1): S3-S9.

4. Lipton SA. Failures and successes of NMDA receptor antagonists: molecular basis for the use of open-channel blockers like memantine in the treatment of acute and chronic neurologic insults. NeuroRx 2004; 1: 101-110.

5. Brennan AM, Suh SW, Won SJ, Narasimhan P, Kauppinen TM, Lee $\mathrm{H}$ et al. NADPH oxidase is the primary source of superoxide induced by NMDA receptor activation. Nat Neurosci 2009; 12: 857-863.

6. Lafon-Cazal M, Pietri S, Culcasi M, Bockaert J. NMDA-dependent superoxide production and neurotoxicity. Nature 1993; 364: 535-537.

7. Patel M, Day BJ, Crapo JD, Fridovich I, McNamara JO. Requirement for superoxide in excitotoxic cell death. Neuron 1996; 16: 345-355

8. Sattler R, Xiong Z, Lu WY, Hafner M, MacDonald JF, Tymianski M. Specific coupling of NMDA receptor activation to nitric oxide neurotoxicity by PSD-95 protein. Science 1999; 284: 1845-1848.

9. Pacher P. Beckman JS, Liaudet L. Nitric oxide and peroxynitrite in health and disease. Physiol Rev 2007; 87: 315-424.
10. Keelan J, Vergun O, Duchen MR. Excitotoxic mitochondrial depolarisation requires both calcium and nitric oxide in rat hippocampal neurons. J Physiol 1999; 520(Pt 3): 797-813.

11. Stout AK, Raphael HM, Kanterewicz BI, Klann E, Reynolds IJ. Glutamate-induced neuron death requires mitochondrial calcium uptake. Nat Neurosci 1998; 1: 366-373.

12. Girouard H, Wang G, Gallo EF, Anrather J, Zhou P, Pickel VM et al. NMDA receptor activation increases free radical production through nitric oxide and NOX2. J Neurosci 2009; 29: 2545-2552.

13. Alekseenko AV, Lemeshchenko VV, Pekun TG, Waseem TV, Fedorovich SV. Glutamateinduced free radical formation in rat brain synaptosomes is not dependent on intrasynaptosomal mitochondria membrane potential. Neurosci Lett 2012; 513: 238-242.

14. Guemez-Gamboa A, Estrada-Sanchez AM, Montiel T, Paramo B, Massieu L, Moran J. Activation of NOX2 by the stimulation of ionotropic and metabotropic glutamate receptors contributes to glutamate neurotoxicity in vivo through the production of reactive oxygen species and calpain activation. J Neuropathol Exp Neurol 2011; 70: 1020-1035.

15. Reyes RC, Brennan AM, Shen Y, Baldwin Y, Swanson RA. Activation of neuronal NMDA receptors induces superoxide-mediated oxidative stress in neighboring neurons and astrocytes. J Neurosci 2012; 32: 12973-12978.

16. Chen H, Yoshioka H, Kim GS, Jung JE, Okami N, Sakata H et al. Oxidative stress in ischemic brain damage: mechanisms of cell death and potential molecular targets for neuroprotection. Antioxid Redox Signal 2010; 14: 1505-1517.

17. Behrens MM, Ali SS, Dao DN, Lucero J, Shekhtman G, Quick KL et al. Ketamine-induced loss of phenotype of fast-spiking interneurons is mediated by NADPH-oxidase. Science 2007: 318: 1645-1647.

18. Sorce S, Krause KH. NOX enzymes in the central nervous system: from signaling to disease. Antioxid Redox Signal 2009; 11: 2481-2504.

19. Bedard K, Krause KH. The NOX family of ROS-generating NADPH oxidases: physiology and pathophysiology. Physiol Rev 2007; 87: 245-313.

20. Dang PM, Fontayne A, Hakim J, El Benna J, Perianin A. Protein kinase C zeta phosphorylates a subset of selective sites of the NADPH oxidase component p47phox and participates in formyl peptide-mediated neutrophil respiratory burst. J Immunol 2001; 166: 1206-1213.

21. Kim JI, Lee HR, Sim SE, Baek J, Yu NK, Choi JH et al. Pl3Kgamma is required for NMDA receptor-dependent long-term depression and behavioral flexibility. Nat Neurosci 2011; 14: 1447-1454.

22. Waxman EA, Lynch DR. N-methyl-D-aspartate receptor subtype mediated bidirectional control of p38 mitogen-activated protein kinase. J Biol Chem 2005; 280: 29322-29333.

23. Wang PY, Petralia RS, Wang YX, Wenthold RJ, Brenowitz SD. Functional NMDA receptors at axonal growth cones of young hippocampal neurons. J Neurosci 2011; 31: 9289-9297.

24. Leevers SJ, Vanhaesebroeck B, Waterfield MD. Signalling through phosphoinositide 3-kinases: the lipids take centre stage. Curr Opin Cell Biol 1999; 11: 219-225.

25. Cuesto G, Enriquez-Barreto L, Carames C, Cantarero M, Gasull X, Sandi C et al. Phosphoinositide-3-kinase activation controls synaptogenesis and spinogenesis in hippocampal neurons. J Neurosci 2011; 31: 2721-2733.

26. Sasaki J, Kofuji S, Itoh R, Momiyama T, Takayama K, Murakami H et al. The Ptdlns $(3,4) \mathrm{P}(2)$ phosphatase INPP4A is a suppressor of excitotoxic neuronal death. Nature 2010; 465: 497-501.

27. Griffin RJ, Moloney A, Kelliher M, Johnston JA, Ravid R, Dockery P et al. Activation of Akt PKB, increased phosphorylation of Akt substrates and loss and altered distribution of Akt and PTEN are features of Alzheimer's disease pathology. J Neurochem 2005; 93: 105-117.

28. Uchida K. 4-Hydroxy-2-nonenal: a product and mediator of oxidative stress. Prog Lipid Res 2003; 42: 318-343.

29. Bindokas VP, Jordan J, Lee CC, Miller RJ. Superoxide production in rat hippocampal neurons: selective imaging with hydroethidine. J Neurosci 1996; 16: 1324-1336.

30. Robinson KM, Janes MS, Pehar M, Monette JS, Ross MF, Hagen TM et al. Selective fluorescent imaging of superoxide in vivo using ethidium-based probes. Proc Natl Acad Sci USA 2006; 103: 15038-15043.

31. Rey FE, Cifuentes ME, Kiarash A, Quinn MT, Pagano PJ. Novel competitive inhibitor of $\mathrm{NAD}(\mathrm{P}) \mathrm{H}$ oxidase assembly attenuates vascular $\mathrm{O}(2)(-)$ and systolic blood pressure in mice. Circ Res 2001; 89: 408-414.

32. Paul S, Connor JA. NR2B-NMDA receptor-mediated increases in intracellular $\mathrm{Ca} 2+$ concentration regulate the tyrosine phosphatase, STEP, and ERK MAP kinase signaling. J Neurochem 2010; 114: 1107-1118.

33. Martel MA, Ryan TJ, Bell KF, Fowler JH, McMahon A, Al-Mubarak B et al. The subtype of GluN2 C-terminal domain determines the response to excitotoxic insults. Neuron 2012; 74: 543-556.

34. Fischer G, Mutel V, Trube G, Malherbe P, Kew JN, Mohacsi E et al. Ro 25-6981, a highly potent and selective blocker of N-methyl-D-aspartate receptors containing the NR2B subunit. Characterization in vitro. J Pharmacol Exp Ther 1997; 283: 1285-1292.

35. Choi DW. Ionic dependence of glutamate neurotoxicity. J Neurosci 1987; 7: 369-379.

36. Hyrc KL, Bownik JM, Goldberg MP. Ionic selectivity of low-affinity ratiometric calcium indicators: mag-Fura-2, Fura-2FF and BTC. Cell Calcium 2000; 27: 75-86.

37. Devinney MJ 2nd, Reynolds IJ, Dineley KE. Simultaneous detection of intracellular free calcium and zinc using fura-2FF and FluoZin-3. Cell Calcium 2005; 37: 225-232. 
38. Stanika RI, Villanueva I, Kazanina G, Andrews SB, Pivovarova NB. Comparative impact of voltage-gated calcium channels and NMDA receptors on mitochondria-mediated neuronal injury. J Neurosci 2012; 32: 6642-6650.

39. Wang YB, Wang JJ, Wang SH, Liu SS, Cao JY, Li XM et al. Adaptor protein APPL1 couples synaptic NMDA receptor with neuronal prosurvival phosphatidylinositol 3-kinase/Akt pathway. J Neurosci 2012; 32: 11919-11929.

40. Jiang D, Sims CE, Allbritton NL. Single-cell analysis of phosphoinositide 3-kinase and phosphatase and tensin homolog activation. Faraday Discuss 2011; 149: 187-200; discussion 227-145.

41. Sacktor TC, Osten $P$, Valsamis $H$, Jiang $X$, Naik MU, Sublette E. Persistent activation of the zeta isoform of protein kinase $\mathrm{C}$ in the maintenance of long-term potentiation. Proc Natl Acad Sci USA 1993; 90: 8342-8346.

42. Serrano $P$, Yao $Y$, Sacktor TC. Persistent phosphorylation by protein kinase Mzeta maintains late-phase long-term potentiation. J Neurosci 2005; 25: 1979-1984.

43. Brunet A, Datta SR, Greenberg ME. Transcription-dependent and -independent control of neuronal survival by the PI3K-Akt signaling pathway. Curr Opin Neurobiol 2001; 11: 297-305.

44. Chou MM, Hou W, Johnson J, Graham LK, Lee MH, Chen CS et al. Regulation of protein kinase C zeta by PI 3-kinase and PDK-1. Curr Biol 1998; 8: 1069-1077.

45. Budd SL, Nicholls DG. Mitochondria, calcium regulation, and acute glutamate excitotoxicity in cultured cerebellar granule cells. J Neurochem 1996; 67: 2282-2291.

46. Sattler R, Charlton MP, Hafner M, Tymianski M. Distinct influx pathways, not calcium load, determine neuronal vulnerability to calcium neurotoxicity. J Neurochem 1998; 71 : 2349-2364.

47. Nakazawa T, Komai S, Tezuka T, Hisatsune C, Umemori H, Semba $\mathrm{K}$ et al. Characterization of Fyn-mediated tyrosine phosphorylation sites on GluR epsilon 2 (NR2B) subunit of the N-methyl-D-aspartate receptor. J Biol Chem 2001; 276: 693-699.

48. Hisatsune C, Umemori H, Mishina M, Yamamoto T. Phosphorylation-dependent interaction of the N-methyl-D-aspartate receptor epsilon 2 subunit with phosphatidylinositol 3-kinase. Genes Cells 1999; 4: 657-666

49. Koponen S, Kurkinen K, Akerman KE, Mochly-Rosen D, Chan PH, Koistinaho J. Prevention of NMDA-induced death of cortical neurons by inhibition of protein kinase Czeta. J Neurochem 2003; 86: 442-450.
50. Volk LJ, Bachman JL, Johnson R, Yu Y, Huganir RL. PKM-zeta is not required for hippocampal synaptic plasticity, learning and memory. Nature 2013; 493: 420-423.

51. Lee AM, Kanter BR, Wang D, Lim JP, Zou ME, Qiu C et al. Prkcz null mice show normal learning and memory. Nature 2013; 493: 416-419.

52. Nakanishi $\mathrm{H}$, Brewer KA, Exton JH. Activation of the zeta isozyme of protein kinase $\mathrm{C}$ by phosphatidylinositol 3,4,5-trisphosphate. J Biol Chem 1993; 268: 13-16.

53. Le Good JA, Ziegler WH, Parekh DB, Alessi DR, Cohen P, Parker PJ. Protein kinase C isotypes controlled by phosphoinositide 3-kinase through the protein kinase PDK1. Science 1998; 281: 2042-2045.

54. Fontayne A, Dang PM, Gougerot-Pocidalo MA, El-Benna J. Phosphorylation of p47phox sites by PKC alpha, beta II, delta, and zeta: effect on binding to p22phox and on NADPH oxidase activation. Biochemistry 2002; 41: 7743-7750.

55. Lafon-Cazal M, Perez V, Bockaert J, Marin P. Akt mediates the anti-apoptotic effect of NMDA but not that induced by potassium depolarization in cultured cerebellar granule cells. Eur J Neurosci 2002; 16: 575-583.

56. Papadia S, Stevenson P, Hardingham NR, Bading H, Hardingham GE. Nuclear $\mathrm{Ca} 2+$ and the cAMP response element-binding protein family mediate a late phase of activity-dependent neuroprotection. J Neurosci 2005; 25: 4279-4287.

57. Massaad CA, Klann E. Reactive oxygen species in the regulation of synaptic plasticity and memory. Antioxid Redox Signal 2010; 14: 2013-2054.

58. Kauppinen TM, Swanson RA. Poly(ADP-ribose) polymerase-1 promotes microglial activation, proliferation, and matrix metalloproteinase-9-mediated neuron death. J Immunol 2005; 174: 2288-2296.

59. Giordano G, Hong S, Faustman EM, Costa LG. Measurements of cell death in neuronal and glial cells. Methods Mol Biol 2011; 758: 171-178.

(c) (i) $\Theta$ Cell Death and Disease is an open-access journal published by Nature Publishing Group. This work is licensed under a Creative Commons Attribution-NonCommercialNoDerivs 3.0 Unported License. To view a copy of this license, visit http://creativecommons.org/licenses/by-nc-nd/3.0/

\section{Supplementary Information accompanies this paper on Cell Death and Disease website (http://www.nature.com/cddis)}

